Article

\title{
Reuse of Waste Geothermal Brine: Process, Thermodynamic and Economic Analysis
}

\author{
Mauro Capocelli ${ }^{1, *(\mathbb{D}}$, Eugenio Moliterni ${ }^{1}$, Vincenzo Piemonte ${ }^{2}$ and Marcello De Falco ${ }^{1}$ \\ 1 Unit of Process Engineering, Department of Engineering, University Campus Bio-Medico di Roma, \\ via Álvaro del Portillo 21, 00128 Rome, Italy; m.defalco@unicampus.it (M.D.F.); \\ eugenio.moliterni@gmail.com (E.M.) \\ 2 Unit of Chemical-physics Fundamentals in Chemical Engineering, Department of Engineering, \\ University Campus Bio-Medico di Roma, via Álvaro del Portillo 21, 00128 Rome, Italy; \\ v.piemonte@unicampus.it \\ * Correspondence: m.capocelli@unicampus.it; Tel.: +39-062-2541-9215
}

Received: 18 November 2019; Accepted: 15 January 2020; Published: 21 January 2020

\begin{abstract}
Geothermal brines can be a resource of energy, freshwater and minerals. Even when rejected after their exploitation to produce energy in a power plant, the brines can be a source of freshwater and minerals, and can have a residual enthalpy that can be recovered to produce additional power. The different reuse scenarios of these wasted brines depend on the composition and temperature at which they must be reinjected into the wells. On this basis, geothermal energy production is a perfect case study to investigate the water-energy nexus and to optimize the integrated energy- and water-production processes. In this paper, two case studies of brine reuse for both energy and water production are presented with the related process analysis, basic design and technical-economic analysis. A methodology to evaluate the exergy efficiency of the processes is presented by analyzing minimum work of separation, the maximum achievable work and the additional primary energy required for integrated production. The novel approach to estimate the process efficiency for integrated geothermal energy and desalination plants is applied to the case studies and discussed in light of literature results.
\end{abstract}

Keywords: exergy analysis; geothermal energy; desalination; organic Rankine cycle; mechanical vapor compression; wastewater

\section{Introduction}

The future freshwater and energy supplies are intrinsically linked and are governed by population growth and ongoing climate change [1]. "Affordable and clean energy" as well as "clean water and sanitation" are two of the UN Sustainable Development Goals and are fundamental to attain almost all the other goals [2]. Both the performances of industrial processes and, more in general, the quality of life depend on energy/water utilization and the nexus between these "primary resources," which are widely discussed in the literature [1-5]. In this sense, it is possible to summarize the water/energy nexus through the following considerations that highlight the opportunity for managing the issues of water and energy supply in an integrated form [5-10].

Water and energy are key drivers of economic growth and social development, and the procurement of these resources is one of the major causes of international conflicts [2,3]. The population growth by 2035 will cause a 35\% increase in energy consumption and an 85\% increase in water consumption; the number of people having unreliable access to electricity are around 2.5 billion, in turn, the number of people living in high-water stress areas are around 2.8 billion [1-3,11,12]. 
The energy sector is among the main sectors responsible for climate change that, in turn, is increasing the stress on water resources through an irreversible modification of the paths and intensities of the rain cycle.

Most energy generation processes require water consumption [1,4,5]; on the other hand, any water treatment/production process requires energy [1,4]. For example, the energy demand of water processes goes from 0.5 for conventional wastewater treatment to $10 \mathrm{kWh} / \mathrm{el} / \mathrm{m}^{3}$ for thermal desalination processes $[8,9,11,12]$.

Moreover, there is a need to decarbonize the water sector (as for the energy one); water production processes, in particular, desalination technologies, are strongly related to the fossil fuel combustion and show a relatively high carbon footprint $\left(1.5-5 \mathrm{kgCO}_{2} / \mathrm{m}^{3}\right)[1,2,11]$. On the other hand, a substantial number of countries affected by water scarcity are energy and fuel exporters, and these countries present enormous potential for developing renewables [11].

This work focuses on the opportunity for recovering precious resources (water, energy and minerals) from wasted brines and the exergy efficiency of the related processes. The over-abstraction and wasting of waters cause pollution and consumption of our "renewable" reservoirs. On the other hand, wastewaters can be considered as an unexploited resource and should be utilized with a more efficient approach, based on three pillars [7-12]:

- water harvesting from nonconventional sources in a closed cycle (e.g., wastewater reuse, "zero-liquid-discharge," circular economy approach) [11,12];

- reduction of the energy (and carbon footprint) of the water processes towards the implementation of renewable energy and energy recovery from water streams [6-9];

- mineral and precious resources recovery from the rejected brine and concentrated effluents [10,13-15].

Although geothermal brines represent a niche with respect to the civil wastewaters, they are the best example of unexploited waste streams that can be used to recover water, minerals and energy [13-18], and offer the ideal case study for the coupling between water production processes and renewable energy utilization [19-23].

The global capacity of geothermal energy has exceeded the value of 13 GW for electricity production, while the direct use (air conditioning, district heating and cooling) and ground-source heat pumps (GSHP) account for more than $70 \mathrm{GW}$ of thermal power [19-21]. Although this renewable resource is available locally, it has the main advantages of low operating costs, good reliability and "dispatchability," since it relies on conventional technologies to convert thermal power to electricity and does not depend on the solar energy, like other renewables [21-23]. Its exploitation is constantly increasing, thanks to enhanced geothermal systems (EGS) that create the acceptable conditions at new potential sites [24]. On the other hand, this renewable resource is "economically available" only in limited sites located in some specific areas of the planet.

Many authors proposed the exploitation of residual geothermal brines to recover additional energy and/or water and minerals [13-15,24-28]. From the energy recovery point of view, the most concrete answer is offered by the organic Rankine cycles (ORCs), well-established systems capable of achieving acceptable efficiencies at low temperatures [29-31].

From the resource recovery point of view, many desalination processes (mainly thermal-based to exploit low-enthalpy sources) have been applied to geothermal brines, mainly for research and development purposes [14-18,25-28]. Thermal processes can be perfectly integrated with the residual heat from the geothermal plant. Desalination processes can be implemented to treat an external water feed (e.g., seawater), exploiting the geothermal brine as a low-enthalpy source, or directly to desalinate the residual geothermal brine, in order to produce additional water and to concentrate it for the recovery of precious minerals (e.g., lithium [11,16,25,26,32]). Gude described many processes and reported the compositions and characteristics of waste brines that include macro elements of the reservoir rock (such as $\mathrm{Na}^{+}, \mathrm{K}^{+}, \mathrm{Ca}^{2+}, \mathrm{Mg}^{2+}, \mathrm{Cl}^{-}, \mathrm{SO}_{4}{ }^{2-}$ ) and trace compounds (e.g., radium) or pollutants [17]. Boron and silica, if present in high concentrations, represent the most dangerous from 
the technical point of view. Most of the TDS (total dissolved solids) concentrations were reported between $500 \mathrm{mg} / \mathrm{L}$ and $8000 \mathrm{mg} / \mathrm{L}$ [14-18] with very high concentration (above 200,000 mg/L) observed at specific reservoirs [17]. The feed water characteristics should be evaluated to determine a suitable desalination process and the final desired product and end use (potabilization, make-up water for industrial or power processes, agriculture, etc.); it is not economically possible to produce a distillate with the desired characteristics from all types of brine. Moreover, while it is always possible to recover heat from the brine to desalinate an external saline water feed, only in some cases a direct treatment of brine for reuse is achievable. As an example, direct reuse is possible for open-type shallow aquifers near active volcanic areas where the brine reservoir is sustained by atmospheric water. In deeper reservoirs (e.g., closed-type geopressured brine), used geothermal brine should be reinjected because of pressure maintenance and reservoir sustainability. In this case, desalination processes should be considered only for mineral mining and not for freshwater production.

Being able to count on a residual enthalpy in the brine, the thermal processes are the most studied. Thermal processes have an energy demand around and often higher than $10 \mathrm{kWh} / \mathrm{m}^{3}$ [23-27]. Bell was the first to develop a technical-economic analysis of geothermal-driven multieffect distillation (MED) in 1959 [33]. Successively, Wong proposed freshwater generation from the geothermal fluid itself [18]. The development of the first patents and pilot plants is well described by A. Christ [34] that reports a comprehensive economic analysis of the geothermal desalination plants. Depending on the composition and the recovery ratio, membrane processes face significant problems of scaling and fouling. Multi-effect evaporation/distillation (MED), multistage flash distillation (MSF), thermal and mechanical vapor compression (TVC/MVC) are the most studied processes; at lower temperature, membrane distillation and humidification-dehumidification can be interesting alternatives [17,26-28,34-38].

Starting from geothermal brines rejected by "flash" power plants, the possible recovery options are presented in this paper, together with a thermodynamic and process analysis. The thermodynamic analysis follows a novel methodology, here presented and inspired by previous works of this research group [39] and by the "exergy approach" adopted by Lienhard's group at the Massachusetts Institute of Technology (MIT) [39]. Similar works including exergy and thermodynamic analysis are reported in the references [29,39-41]. These approaches enable the rigorous comparison with any other production process because it considers the real quality of the inputs and outputs, and enables the individuation of the "actual process irreversibility" [42-44].

The model presented here allows quantification of the "exergetic efficiency" for both water and energy production and could represent a first reference in the framework of geothermal brine reuse. The process analysis reported here utilizes (as input) real data from geothermal areas belonging to the Italian company, Enel Green Power S.p.A (Rome). The well networks and the power plants of the Enel GP areas (Bagnore, Piancastagnaio, Cove Fort) were analyzed in order to extrapolate the flow rates, temperatures and pressures of the geothermal waste streams that can still be used to produce additional useful work and freshwaters. The solutions of water and energy production were simulated using the Aspen Plus simulator, considering the organic Rankine cycle for power production and mechanical vapor compression (MVC) for desalination. The basic design was developed to realize a prefeasibility study (technical-economic analysis) and the novel methodology for the exergy analysis was adopted to obtain the "actual process efficiencies" and to compare these processes to similar ones, even if not related to a geothermal energy source.

\section{Materials and Methods}

\subsection{Exergy Analysis}

The "exergy" (or second-law) efficiency is the ratio of the exergy output divided by the exergy input and accounts for the "actual" efficiency of processes. It can be applied to any process, from the energy production to the mineral or water extraction/separation. In the case of a "chemical separation box," it enables the comparison between processes utilizing different sources of energy [42-44] and is 
defined by the ratio between the least work of separation (minimum reversible work) and the actual work required. An extended discussion of the second-law efficiency, the least work and least exergy of separation, is given by the recent works of Lienhard's research group at the MIT [39,42-44], especially regarding seawater desalination.

According to these papers, in any separation process, seen as a black box, the energy input can be evaluated in terms of work $\left(\mathrm{W}_{\mathrm{sep}}\right)$ and heat $\left(\mathrm{Q}_{\mathrm{sep}}\right)$ of separation. Since these types of energy have a different quality ("availability" or "exergy"), their value should be compared in terms of "equivalent primary energy" or in relation to the minimum required work or heat.

Equations (1) and (2) report these minimum values, where $r$ is the recovery ratio, $T_{0}$ and $\mathrm{T}_{\mathrm{H}}$ are the temperature of the "cold" (ambient) and "hot" (highest temperature available) thermal sources, as defined by Mistry et al. [39]. These depend on the free Gibbs energy of the feed $\left(g_{f}\right)$, the concentrate $\left(\mathrm{g}_{\mathrm{c}}\right)$ and the product $\left(\mathrm{g}_{\mathrm{p}}\right)$ (distilled or desalinated water in the case of desalination processes). Figure 1 depicts the minimum values for both work-driven desalination and thermal processes at different temperatures.

$$
\begin{gathered}
\frac{\dot{W}_{\text {least }}}{\dot{m}_{p}}=\left(g_{p}-g_{c}\right)-\frac{1}{r}\left(g_{f}-g_{c}\right) \\
\frac{\dot{Q}_{\text {least }}}{\dot{m}_{p}}=\left(1-\frac{T_{0}}{T_{H}}\right)^{-1}\left[\left(g_{p}-g_{c}\right)-\frac{1}{r}\left(g_{f}-g_{c}\right)\right]
\end{gathered}
$$

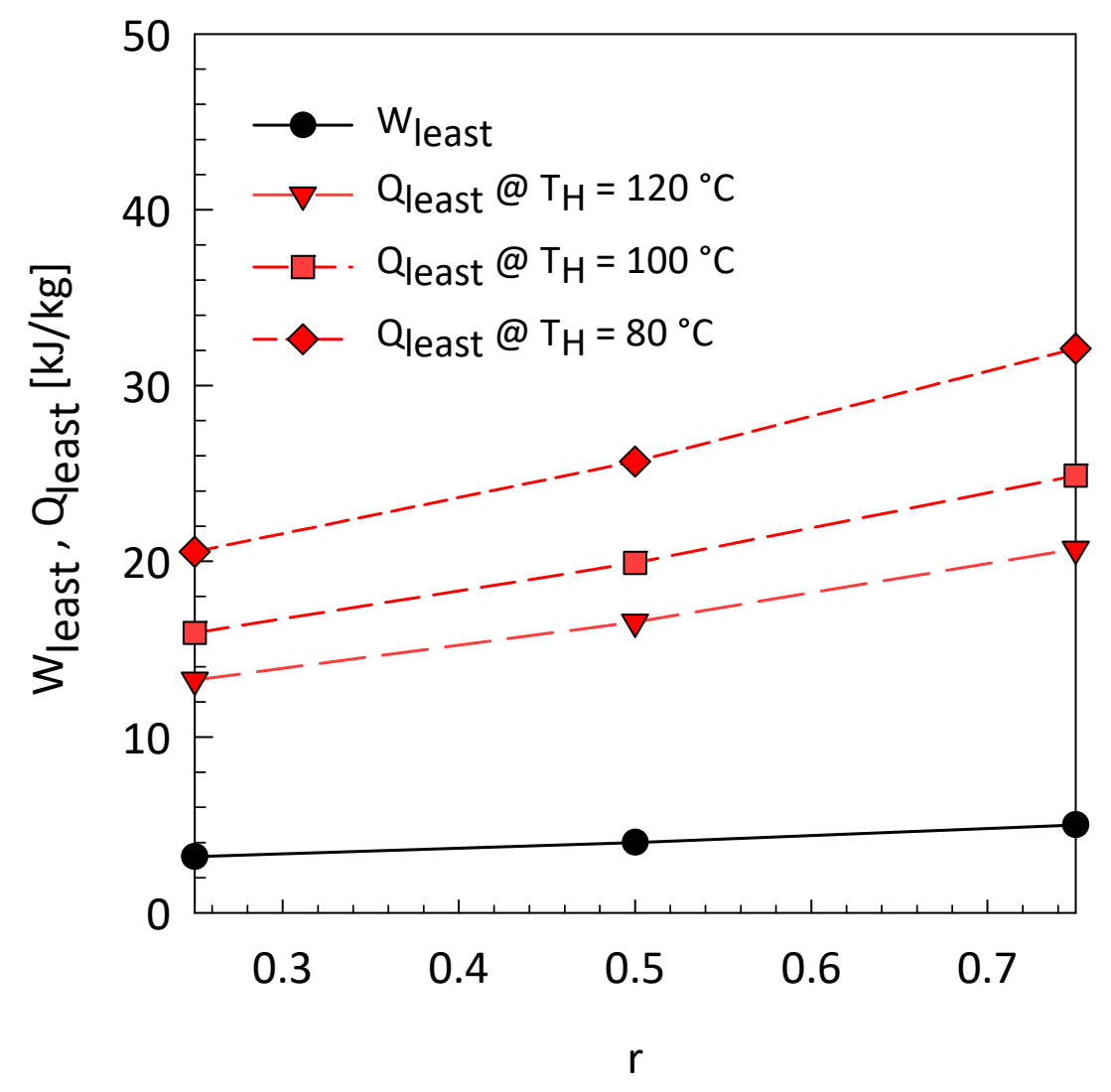

Figure 1. Minimum thermal and electrical energy for the separation of freshwater (product) from seawater (feed salinity at $35,000 \mathrm{ppm}$ and environmental temperature $\mathrm{T}_{0}=25^{\circ} \mathrm{C}$ ) in relation to the recovery ratio, $\mathrm{r}$. 
Hence, the second-law or exergy efficiency (Equation (3)) is the ratio between these minimum values and the "actual" work (or heat) of separation, the energy actually required to carry out the process. Equivalently, this definition can be seen as the ratio of minimum fuel consumption to actual fuel consumption or, as reported in Equation (3), the ratio between the minimum and the actual carbon footprint of the process.

$$
\eta_{I I}=\frac{\xi_{\text {useful }}}{\xi_{\text {used }}}=\frac{\dot{W}_{\text {least }}}{\dot{W}_{\text {real }}}=\frac{\dot{Q}_{\text {least }}}{\dot{Q}_{\text {real }}}=\frac{\text { min } \mathrm{CO}_{2} \text { emission }}{\text { actual } \mathrm{CO}_{2} \text { emission }}
$$

According to the cited literature $[39,44]$, for integrated processes the "real values" of work/heat depend on the energy production system. Especially if the final aim is the minimization of primary energy consumption, fuel consumption and/or carbon emission, these "real values" should be evaluated in a cogeneration scheme (dual-purpose water/energy plants). Following the approach of Mistry et al. [39], the "work value" depends on the global efficiency of the power plant; the "thermal power value" depends on the temperature of the hot source. Here, referring to Figure 2, this methodology is briefly adapted for the geothermal-brine utilization. The overall heat input (primary energy) provided to the system is divided into the power plant amount $\left(\mathrm{Q}_{\mathrm{pp}}\right)$ and the amount necessary to drive the separation process $\left(Q_{\text {des }}\right)$. By applying the first and second laws of thermodynamics and by defining the entropy generation in relation to the "intrinsic efficiency of the power plant," $\eta_{p p}$, it is possible to define the amount of additional energy required for desalination (Equation (4)) and the "modified" second-law efficiency $\eta_{I I}$ (Equation (5)) in analogy to the work of Mistry et al. [38]. It should be noted that the thermal powers and the brine are separated for representation clarity, but may coincide since the heat is actually recovered from the wasted brine that, in turn, could be also the feed of the black box separator.

$$
\begin{gathered}
\dot{Q}_{\text {des }}=\frac{\dot{W}_{s e p}}{\left(1-\frac{T_{0}}{T_{H}}\right) \eta_{p p}}+\dot{Q}_{s e p} \frac{\left(1-\frac{T_{0}}{T_{s}}\right)}{\left(1-\frac{T_{0}}{T_{H}}\right)} \\
\eta_{I I}=\frac{\dot{W}_{\text {least }}}{\frac{\dot{W}_{\text {sep }}}{\eta_{p p}}+\dot{Q}_{\text {sep }}\left(1-\frac{T_{0}}{T_{s}}\right)}
\end{gathered}
$$

In this way, the resulting second-law efficiency of Equation (5) accounts for the "actual amount" of additional energy that must be provided to the power plant in order to generate the required amount of heat and work to power the desalination plant (or any separation plant). In the case of sensible heat recovery (e.g., waste heat, solar and geothermal power), the actual exergy input and the heat of separation should be corrected by considering a temperature-variable heat source as described in the following with the support of Figure 3.

In this case, the "actual exergy input" is lower with respect to the conventional cases where the exergetic input is supplied at a constant or pseudoconstant temperature (e.g. the adiabatic flame temperature for a fossil fuel or the condensation temperature for a steam) and are taken into account though the Carnot efficiency $\left(1-\mathrm{T}_{0} / \mathrm{T}_{\mathrm{H}}\right)$. In the case of sensible heat, the correction factor $\eta_{S H}$ of Equation (6) can be introduced to account for the lower exergetic input. With reference to Figure $3, \eta_{S H}$ considers the exergy variation (decreasing energy availability due to the entropy generation) during the heat transfer from a sensible heat source with respect to the maximum value represented by the Carnot limit.

$$
\eta_{S H}=\frac{\mathrm{Q}_{H} \cdot \eta_{\text {rev }} \text { useful }}{\mathrm{Q}_{H} \cdot \eta_{\text {rev }}}=\frac{\int_{T_{\mathrm{c}}}^{T_{H}} \dot{m} \cdot \mathrm{c}_{p} \cdot \eta_{\text {rev }}(T) \cdot d T}{\int_{T_{0}}^{T_{H}} \dot{m} \cdot \mathrm{c}_{p} \cdot \eta_{\text {rev }} \cdot d T}=\frac{T_{\mathrm{c}}\left[T_{H} / T_{\mathrm{c}}-1-\ln \left(T_{H} / T_{\mathcal{c}}\right)\right]}{\left(T_{H}-T_{0}\right)\left(1-T_{0} / T_{H}\right)}
$$

Figure 4 shows a first sensitivity analysis to understand the order of magnitude of this correction factor. The temperature of the hot source varies in the range $60-110^{\circ} \mathrm{C}$. The environment temperature 
$T_{0}$ was kept constant at $40{ }^{\circ} \mathrm{C}$. The lower temperature $T_{c}$ varies from $T_{0}$ to $T_{0}+\Delta T$. The results show that the "energy availability" of sensible heat source at $\mathrm{T}_{\mathrm{H}}$ is lower than the exergetic content of a constant temperature (latent heat) source at the same temperature $\mathrm{T}_{\mathrm{H}}$. The reduction factor is always less than 0.5 and assumes very low values by decreasing the maximum temperature of the hot source $\mathrm{T}_{\mathrm{H}}$ and with the increase of the terminal temperature pinch difference $\Delta \mathrm{T}$.

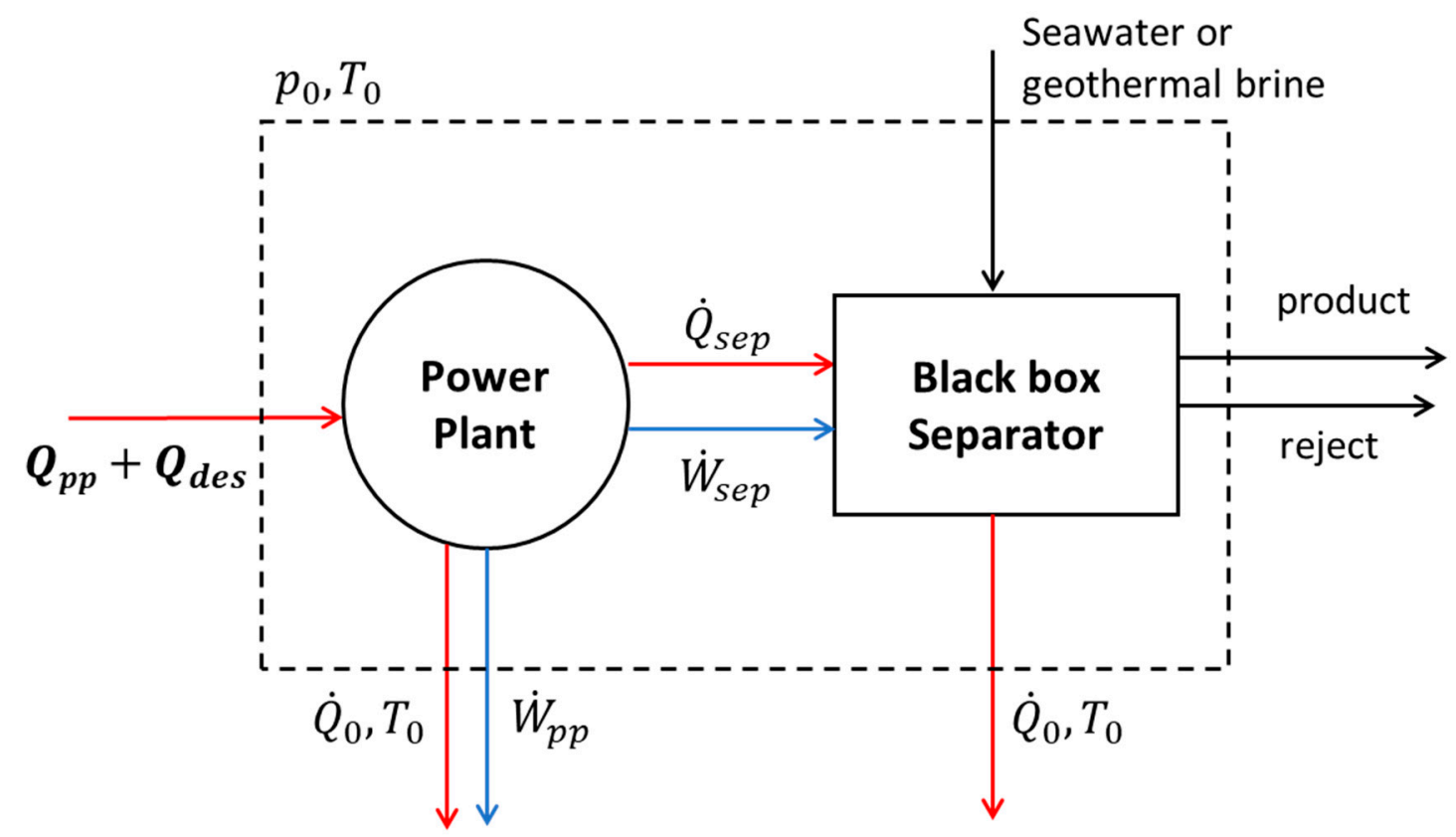

Figure 2. Control volumes for an arbitrary black box chemical separator in a dual purpose water/energy plant, adapted from Mistry and Lienhardt [38,42,43].

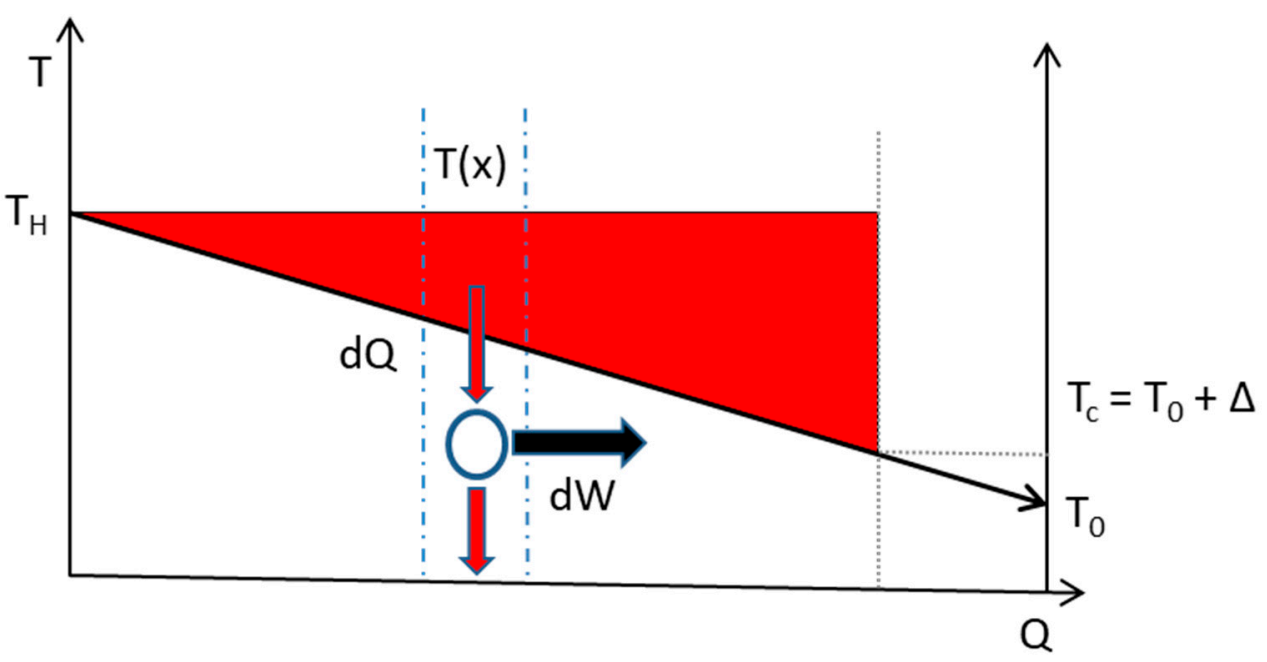

Figure 3. Enthalpy (thermal power) vs. temperature graph relative to a heat exchanger to recover the sensible heat of a hot stream from $\mathrm{T}_{\mathrm{H}}$ to $\mathrm{T}_{\mathrm{c}}$. 


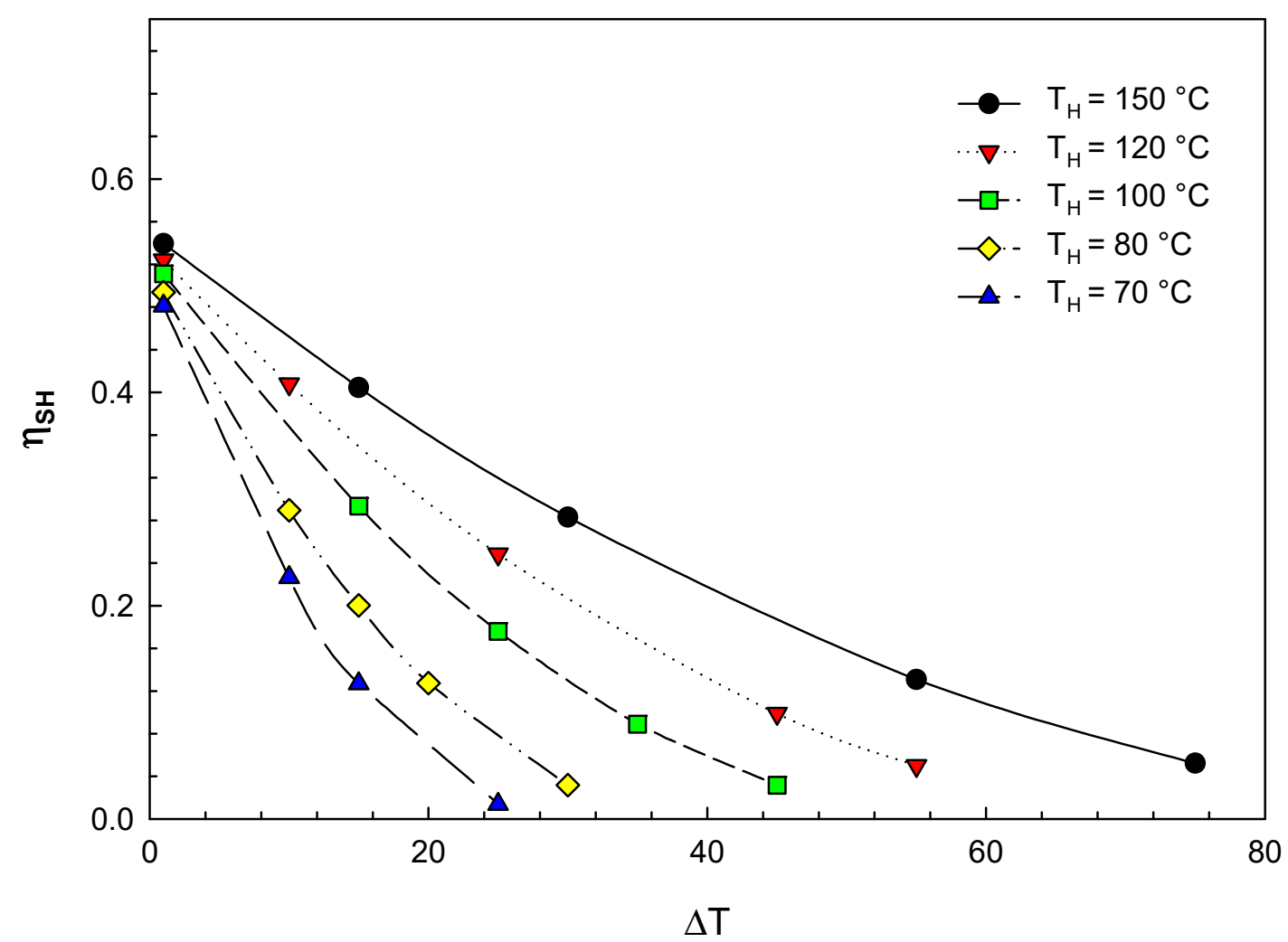

Figure 4. Theoretical values of the correction factor for "sensible heat sources" $\eta_{S H}$ in relation to the "hot and cold" temperatures, $\mathrm{T}_{\mathrm{H}}$ and $\mathrm{T}_{\mathrm{C}}$.

Therefore, any actual thermal exergy input should be modified as reported by Equation (7). With this premise, the proposed second-law efficiency of separation should be replaced by Equation (8), where $\eta_{S H}^{T_{H}}$ is the correction factor for sensible heat, calculated at $\mathrm{T}_{\mathrm{H}}$.

$$
\begin{gathered}
\Xi_{t h}=Q\left(1-\frac{T_{0}}{T_{H}}\right) \eta_{S H}^{T_{H}} \\
\eta_{I I}=\frac{\dot{W}_{\text {least }}}{\left[\frac{\dot{W}_{\text {sep }}}{\eta_{p p}}+\dot{Q}_{\text {sep }}\left(1-\frac{T_{0}}{T_{S}}\right) \eta_{S H}^{T_{S}}\right] \eta_{S H}^{T_{H}}}
\end{gathered}
$$

As regards the integrated production process (dual water/energy production plant), Equation (9) should be adopted, based on the following assumptions:

- the incoming sensible heat is evaluated as described above;

- the exergy of the output work or electric power is equal to the work output value $\mathrm{W}_{\mathrm{pp}}$;

- the exergy value of the distilled water product (output) is equal to the minimum reversible work of separation $\mathrm{W}_{\text {least }}$ (i.e., the difference in Gibbs free energy between the product and the concentrate, as defined by Equation (1)).

$$
\eta_{I I}^{\text {dual }}=\frac{W_{p p}+W_{\text {least }}}{\left(Q_{p p}+Q_{\text {des }}\right)\left(1-\frac{T_{0}}{T_{H}}\right) \eta_{S H}^{T_{H}}}
$$

\subsection{Case Studies and Brine Characterization}

For the first case study (related to the energy production), we report brine characterization from two single flash plants (area of Bagnore and of Piancastagnaio, Tuscany, Italy). Table 1 reports 
the operating conditions, flow rate and composition of brine streams reinjected into the wells. The characterization includes the dissolved gases (needed for the basic design of the heat exchangers). For the electricity generation (by recovering the sensible heat available in the waste brine) the organic Rankine cycle is adopted, as discussed in the following section.

Table 1. Characterization of the waste streams reinjected in the wells network of the geothermal areas.

\begin{tabular}{cccccccccc}
\hline & \multicolumn{3}{c}{ Bagnore } & \multicolumn{5}{c}{ Piancastagnaio } \\
\hline Variable & B1 & B2 & B3 & P1 & P2 & P3 & P4 & P5 & P6 \\
\hline Total Flow $\left(\mathrm{kg} \mathrm{h}^{-1}\right)$ & 30,000 & 120,030 & 77,475 & 40,008 & 40,008 & 7002 & 12,002 & 1501 & 50,008 \\
$\mathrm{H}_{2}$ O Flow $\left(\mathrm{kg} \mathrm{h}^{-1}\right)$ & 29,995 & 120,010 & 77,473 & 40,000 & 40,000 & 7001 & 12,000 & 1500 & 50,000 \\
$\mathrm{CO}_{2}$ Flow $\left(\mathrm{kg} \mathrm{h}^{-1}\right)$ & 2.93 & 11.71 & 0.49 & 4.88 & 4.89 & 0.81 & 1.39 & 0.20 & 4.44 \\
$\mathrm{H}_{2}$ S Flow $\left(\mathrm{kg} \mathrm{h}^{-1}\right)$ & 2.11 & 8.45 & 0.59 & 3.35 & 3.35 & 0.56 & 0.97 & 0.13 & 3.25 \\
Temperature $\left({ }^{\circ} \mathrm{C}\right)$ & 190.0 & 190.0 & 148.5 & 212.9 & 212.9 & 207.0 & 210.7 & 210.9 & 196.5 \\
Pressure $($ bar) & 13.5 & 13.0 & 4.5 & 20.4 & 20.4 & 18.0 & 19.5 & 19.5 & 14.4 \\
Vapor Fraction & 0.00 & 0.00 & 0.00 & 0.00 & 0.00 & 0.02 & 0.01 & 0.02 & 0.02 \\
Liquid Fraction & 1.00 & 1.00 & 1.00 & 1.00 & 1.00 & 0.98 & 0.99 & 0.98 & 0.98 \\
\hline
\end{tabular}

The second case study is related to the freshwater production (by means of desalination technologies) from the waste brines (direct desalination). This process is applied to the medium-enthalpy binary-cycle geothermal power plant of "Cove Fort," having a capacity of $25 \mathrm{MW}$, for a total of $160 \mathrm{GWh}$ of electricity produced per year. The brine composition (averaged from several reinjection wells) is reported in Table 2. The purpose of the water recovery is to produce fire-fighting water, demineralized water, drinking water and service water in order to make this plant self-sufficient from a water standpoint. This means that the plant productivity has been limited to these purposes.

Table 2. Composition, temperature, pressure and flow data for geothermal brine leaving the Cove Fort plant.

\begin{tabular}{cc}
\hline Variable & Value \\
\hline Flow Rate $(\mathrm{t} / \mathrm{h})$ & 2251.86 \\
Outlet Temperature Tout $\left({ }^{\circ} \mathrm{C}\right)$ & 75.44 \\
Outlet Pressure bara & 9.08 \\
$\mathrm{pH}$ & 5.6 \\
Flow $(\mathrm{KPH})$ & 4971.0 \\
\hline Total Dissolved Solids (TDS) $(\mathrm{mg} / \mathrm{L})$ & 4184.8 \\
\hline $\mathrm{Cl}(\mathrm{mg} / \mathrm{L})$ & 1921.7 \\
$\mathrm{Si}(\mathrm{mg} / \mathrm{L})$ & 187.0 \\
$\mathrm{~K}(\mathrm{mg} / \mathrm{L})$ & 252.4 \\
$\mathrm{Na}(\mathrm{mg} / \mathrm{L})$ & 1194.5 \\
$\mathrm{Na} / \mathrm{K}$ & 4.7 \\
$\mathrm{Ca}(\mathrm{mg} / \mathrm{L})$ & 73.5 \\
\hline
\end{tabular}

\section{Results and Discussion}

\subsection{Energy Production}

The process scheme and the main assumptions for the additional energy generation is described in the following. Given the low temperature of the thermal source, an organic Rankine cycle with isobutane as the working fluid was chosen. For the first area (Bagnore), the choice fell on the union of the three streams (B1-3 of Table 1) and the generation of a single liquid/vapor feed (vapor content $>5 \%$ ) at $148.54^{\circ} \mathrm{C}$ and 4.5 bar. The process scheme is depicted in Figure 5. The optimal solution to optimize the heat recovery and the related power production was to feed a first separator (flash) to produce a vapor stream and a liquid stream. The vapor stream is then sent to the evaporator of the 
Rankine cycle, while the liquid is sent to the economizer (preheater) together with the condensate from the evaporator. In the Aspen flowsheet for simulation, the heat exchange is regulated by a design specification manipulating the isobutane flow rate (corresponding to the control valve of Figure 5) to obtain $99 \%$ liquid in the condensate stream out from the hot side of the evaporator. This "practical" value was selected since total condensation is not possible because of incondensable gases in the steam. Isobutane (critical temperature of $134.92^{\circ} \mathrm{C}$ and critical pressure of 35.85 bar) was selected to recover the heat from the saturated streams of water (at the inlet temperature $\mathrm{T}_{\mathrm{H}}$ of $148.54^{\circ} \mathrm{C}$ ). The temperature-enthalpy diagram of the waste heat recovery exchangers is depicted in Figure 6 . The evaporating pressure of $30 \mathrm{bar}\left(\mathrm{T}=123^{\circ} \mathrm{C}\right)$ allows an acceptable temperature pinch difference $\left(\sim 5^{\circ} \mathrm{C}\right)$. The chosen pressure value provides the maximum vapor quality (saturated vapor enthalpy) at the lowest price (latent heat of vaporization). The discharge pressure of the turbine was chosen at 5 bar (corresponding to a condensation temperature of $38^{\circ} \mathrm{C}$ ).

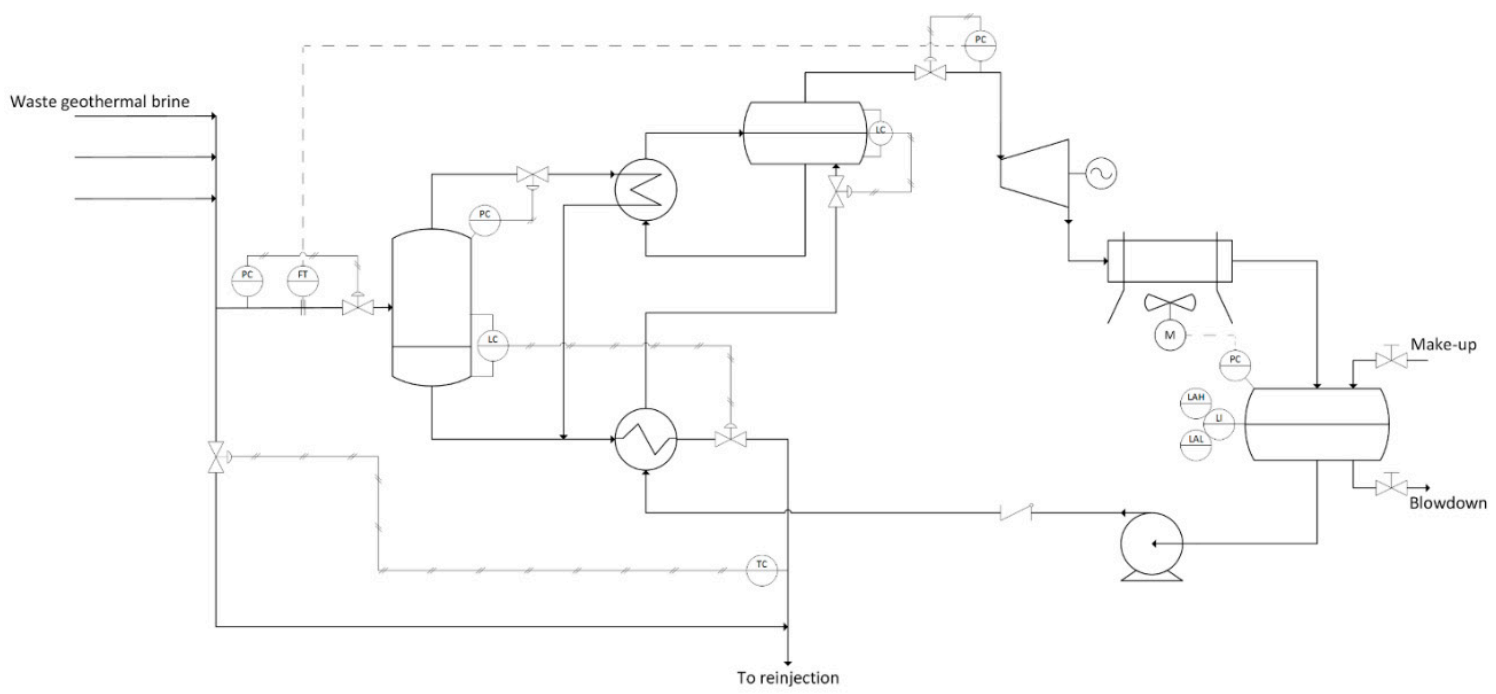

Figure 5. Process scheme of the proposed solution for energy recovery (case study 1a, Bagnore).

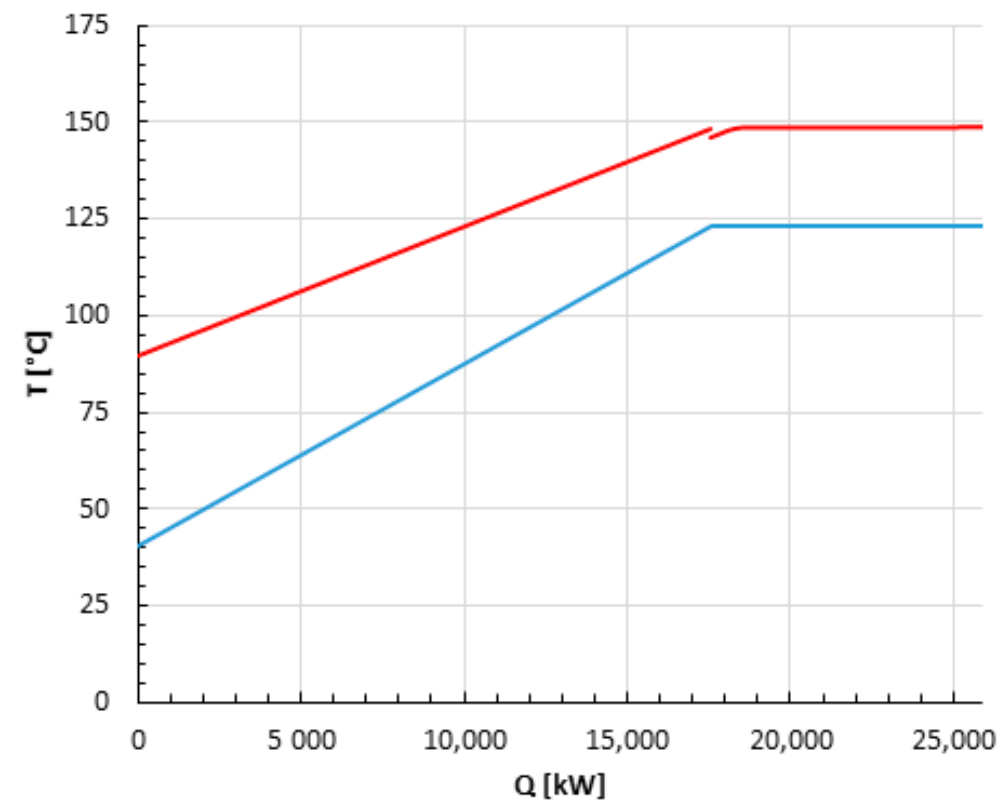

Figure 6. Temperature-enthalpy diagram of the waste heat recovery for the case study 1a, Bagnore). 
For the second area (Piancastagnaio), the union of all the streams results in a liquid/vapor stream at $196.5^{\circ} \mathrm{C}$ and 14.4 bar (with a percentage of vapor lower than $5 \%$ ) that can be directly exploited as a sensible heat source in the evaporator. The simplified process scheme (symbolically equivalent to the flowsheet realized for the Aspen simulation) is shown in Figure 7. The heat exchange of the cycle is controlled by manipulating the flow rate of the working fluid in the closed cycle in order to have a pinch of $5{ }^{\circ} \mathrm{C}$ between the brine leaving the evaporator and the working fluid stream (saturated liquid) entering the evaporator. An additional exchanger to recover the heat from the superheated steam leaving the turbine (before entering the condenser) was included in the process scheme. In this way, the liquid feed is preheated, thus increasing the cycle efficiency. After a preliminary process optimization, isopentane (with critical temperature of $187.83{ }^{\circ} \mathrm{C}$ and a critical pressure of $34.09 \mathrm{bar}$ ) was selected to recover the heat of the waste geothermal brine at $196.5^{\circ} \mathrm{C}$ (with the similar preliminary considerations adopted for the previous power cycle). The temperature-enthalpy diagram of the waste heat recovery is depicted in Figure 8. The discharge pressure of the turbine was chosen at $1.5 \mathrm{bar}$ (corresponding to a condensing temperature of $39^{\circ} \mathrm{C}$ ).

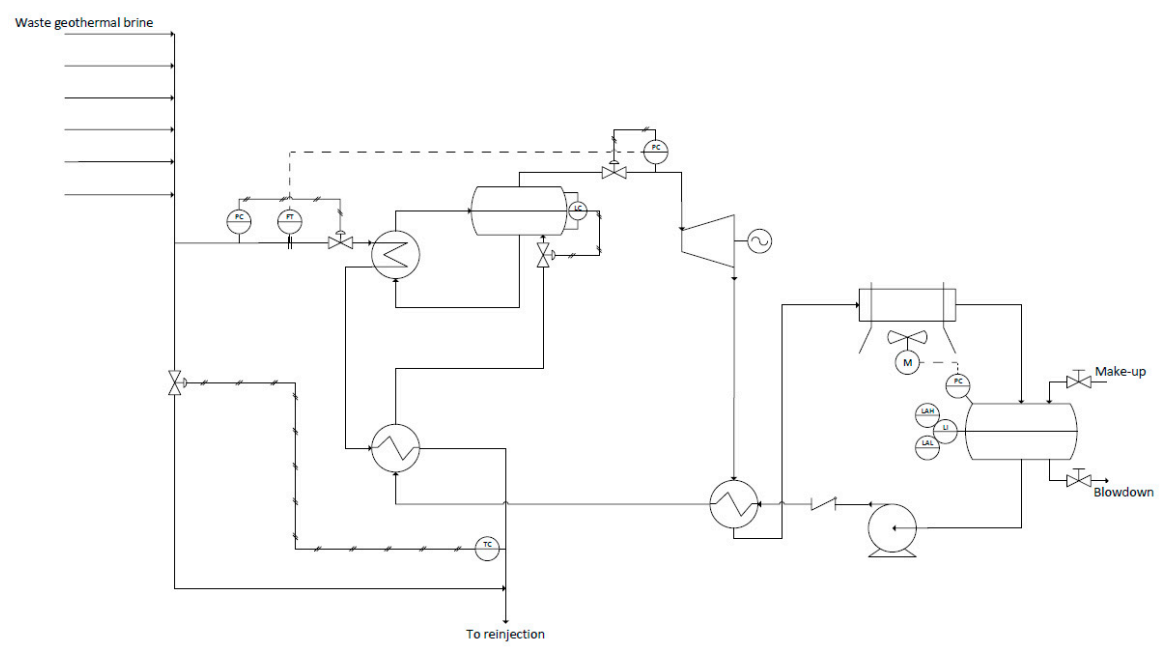

Figure 7. Process scheme of the proposed solution for energy recovery (case study $1 b$, Piancastagnaio).

For both these power plants, the thermodynamic model adopted for the Aspen Plus simulation was the Peng-Robinson. The noncondensable gases $\left(\mathrm{CO}_{2}\right.$ and $\left.\mathrm{H}_{2} \mathrm{~S}\right)$ leaving the wells were taken into account and their distribution between the liquid and the steam (downstream of the separators) was considered. The results of the process analysis, after a preliminary stage of optimization (not included in this paper) is reported and summarized in Table 3. It is possible to recover around $3 \mathrm{MW}$ for case 1a and $4 \mathrm{MW}$ for case $1 \mathrm{~b}$. The adiabatic isentropic efficiency and the organic efficiency were assumed at 0.8 and 0.9 , respectively. These values give a thermal efficiency of 0.10 and 0.17 , respectively, for cases $1 \mathrm{a}$ and $1 \mathrm{~b}$.

On the other hand, the exergy efficiency, considering the quality of the thermal energy input according to Equation (9) (where there is no production of water and the reversible work of separation $\mathrm{W}_{\text {rev }}$ is put equal to zero) is higher than 0.6 , indicating that the electricity generation is closer to the maximum achievable energy. The second case study presents a very high efficiency, this at the expense of the exchange surfaces which increase, due to the very reduced pinch-point temperature difference $\Delta \mathrm{T}$, as can be seen from the enthalpy-temperature diagram of Figure 8. This methodology in fact allows to make quantifiable the dichotomy between the investment costs and process optimization which, by reducing entropy generation, improves exergy efficiency [45]. 


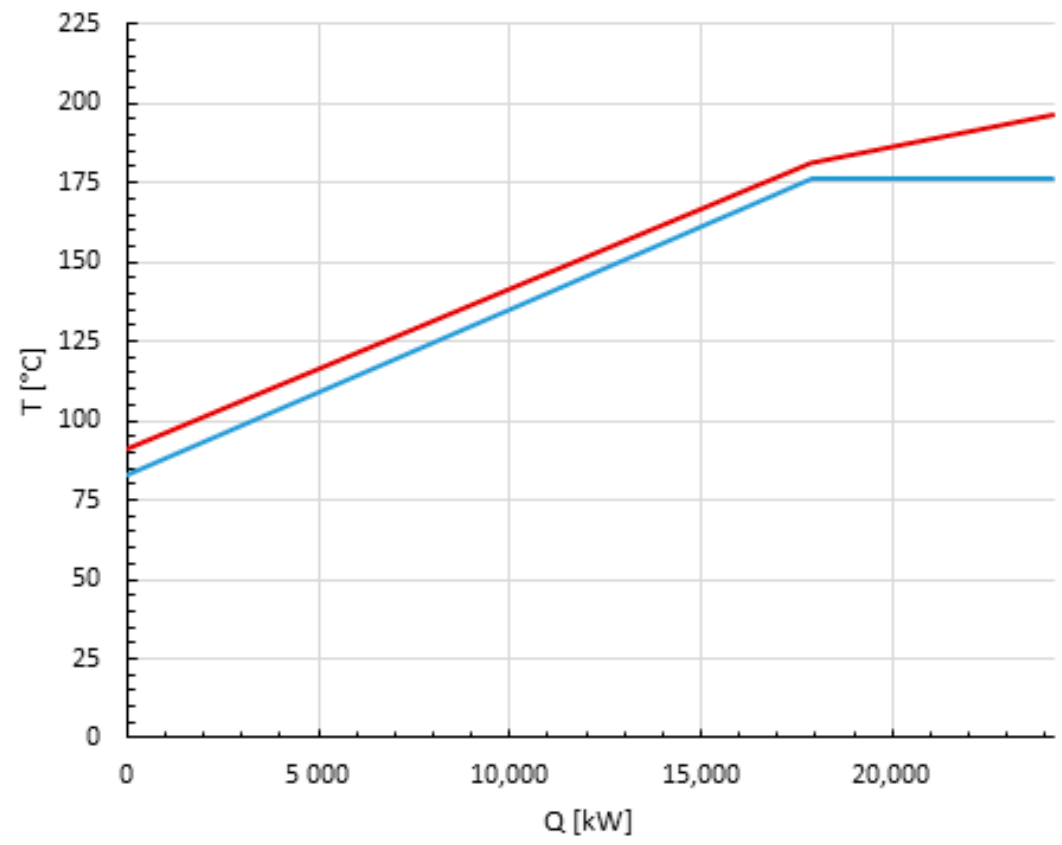

Figure 8. Temperature-enthalpy diagram of the waste heat recovery for the case study 1b, Piancastagnaio.

Table 3. Results of the process basic design-energy recovery for case studies 1a and 1b.

\begin{tabular}{ccc}
\hline Main Results & Case 1a & Case 1b \\
\hline Nominal Power $(\mathrm{MW}]$ & \multicolumn{2}{c}{$\sim 60$} \\
Reinjected Brine Temperature $\left({ }^{\circ} \mathrm{C}\right)$ & 89.4 & 91 \\
Heat Recovered $\mathrm{Q}_{\text {in }}(\mathrm{kW})$ & $25,893.4$ & $24,200.7$ \\
Additional ORC Turbine Power $(\mathrm{kW})$ & 3140 & 4618.3 \\
Auxiliaries $(\mathrm{kW})$ & 428 & 369.8 \\
ORC Global Efficiency $\eta_{g}$ & 0.105 & 0.175 \\
ORC Second-Law Efficiency $\eta_{I I}$ & 0.61 & 0.96 \\
\hline
\end{tabular}

According to the process results, the economic analysis was carried out including the following steps. The capital expenditure (CAPEX) estimation was done by estimating the cost for each equipment from a preliminary basic design. The design/CAPEX results are summarized in Table 4 . The economic results for the key indexes of project profitability and the cost of electricity (CoE) were obtained considering incentives (renewable energy power plants different from photovoltaic) and reported in Table 5.

Table 4. Capital expenditure (CAPEX) and profitability estimation for ORC (case study 1a and 1b).

\begin{tabular}{ccccc}
\hline & \multicolumn{2}{c}{ Case 1a } & \multicolumn{2}{c}{ Case 1b } \\
\hline Equipment & Value & Cost $\mathbf{( k € )}$ & Value & Cost (k€) \\
\hline $\begin{array}{c}\text { Separator (vertical vessel) } \\
\text { Economizer }\end{array}$ & $52 \mathrm{~m}^{3}$ & 272 & & \\
(Heat-Exchanger) & $595 \mathrm{~m}^{2}$ & 258 & $3311 \mathrm{~m}^{2}$ & 895 \\
Evaporator & & & & \\
(Heat-Exchanger) & $401 \mathrm{~m}^{2}$ & 206 & $678 \mathrm{~m}^{2}$ & 279 \\
Recovery Heat-Exchanger & & & $744 \mathrm{~m}^{2}$ & 296 \\
Turbine & $3.14 \mathrm{MW}$ & 1709 & $4.62 \mathrm{MW}$ & 2154 \\
Alternator & $3.77 \mathrm{MW}^{2}$ & 1273 & $5.54 \mathrm{MW}$ & 1830 \\
Condenser (air cooler) & $1600 \mathrm{~m}^{2}$ & 573 & $1844 \mathrm{~m}^{2}$ & 620 \\
\hline
\end{tabular}


Table 4. Cont.

\begin{tabular}{|c|c|c|c|c|}
\hline \multirow[b]{2}{*}{ Fans } & \multicolumn{2}{|c|}{ Case 1a } & \multicolumn{2}{|c|}{ Case $1 b$} \\
\hline & $1899 \mathrm{~m}^{3} / \mathrm{s}$ & 1141 & $1667 \mathrm{~m}^{3} / \mathrm{s}$ & 998 \\
\hline Fans Engine & 404 kW & 151 & 354 kW & 140 \\
\hline Pump & $385 \mathrm{~kW}$ & 179 & $332 \mathrm{~kW}$ & 163 \\
\hline Pump Engine & $462 \mathrm{~kW}$ & 186 & $399 \mathrm{~kW}$ & 173 \\
\hline CAPEX $(\mathrm{k} €)$ & \multicolumn{2}{|c|}{8839} & \multicolumn{2}{|c|}{11228} \\
\hline NPV (k€) (@ r 5\%) & \multicolumn{2}{|c|}{$24,194.65$} & \multicolumn{2}{|c|}{$40,974.81$} \\
\hline IRR & \multicolumn{2}{|c|}{$27 \%$} & \multicolumn{2}{|c|}{$34 \%$} \\
\hline PBP (time) & \multicolumn{2}{|c|}{3 years and 6 months } & \multicolumn{2}{|c|}{3 years } \\
\hline ROI & \multicolumn{2}{|c|}{0.23} & \multicolumn{2}{|c|}{0.29} \\
\hline $\mathrm{CoE}(€ / \mathrm{MWh})$ & \multicolumn{2}{|c|}{65} & \multicolumn{2}{|c|}{54} \\
\hline
\end{tabular}

Table 5. Assumption of the economic drivers for the profitability estimation.

\begin{tabular}{cc}
\hline Input Parameter & Value \\
\hline Electricity price & $65 € / \mathrm{MWh}$ \\
Basic incentive rate & $98 € / \mathrm{MWh}$ \\
Bonus for total reinjection of geothermal brine & $30 € / \mathrm{MWh}$ \\
\hline Total selling price of electricity & $193 € / \mathrm{MWh}$ \\
\hline
\end{tabular}

\subsection{Freshwater Production}

Regarding the water production by desalination technologies, the aforementioned options of brine reuse are depicted in Figure 9. It is possible to use the waste brine as a heating fluid, thereby recovering the heat to preheat a saltwater stream (e.g., seawater) successively sent to the desalination apparatus (Option 2). In some cases the brine itself can be sent to the desalination plant to produce fresh water and a concentrated brine (Option 1). As discussed in the Introduction, the choice depends on the water quality and the end-use; moreover, the second option can also be used to preconcentrate geothermal brines in a perspective of recovering minerals from them.

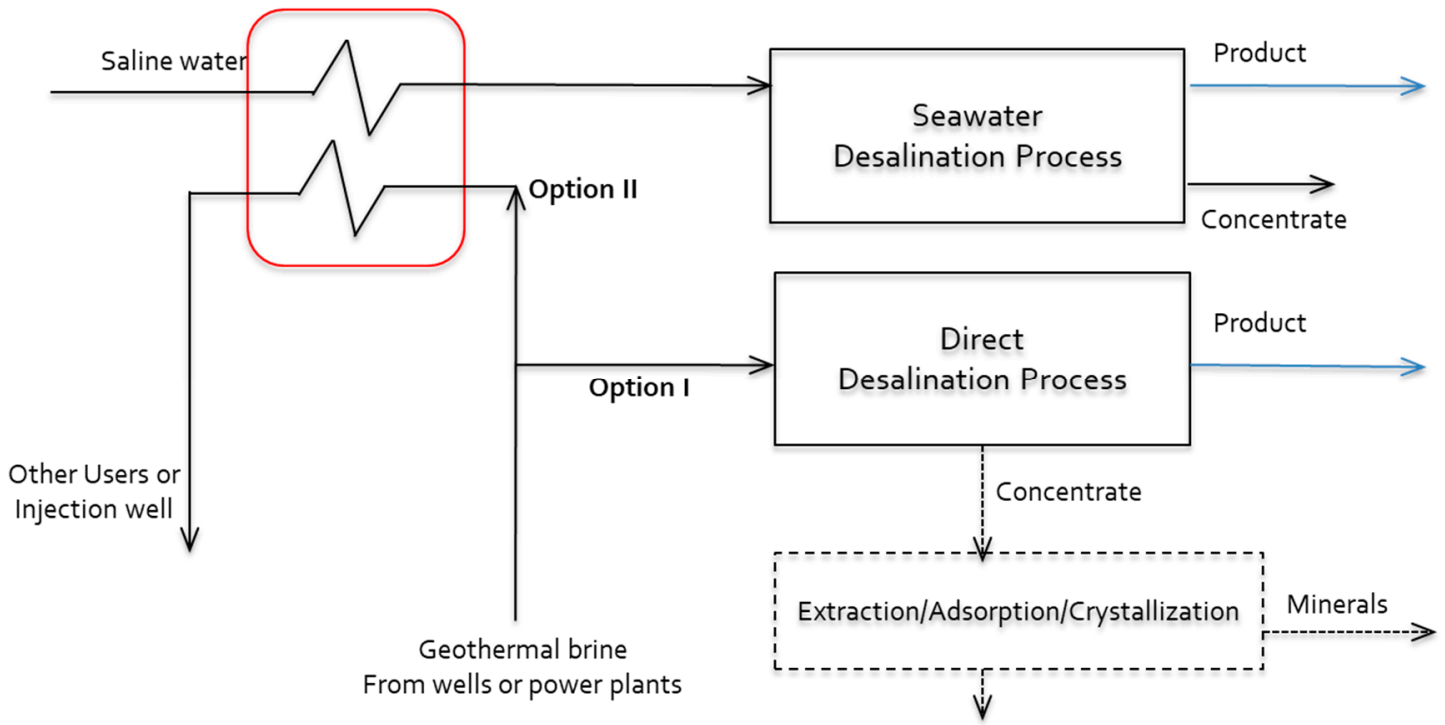

Figure 9. Simplified block diagram of the geothermal desalination options.

From the "exergy point of view," the two options are similar (and the equations proposed in Section 2.1 can be implemented) since the input exergy is always given by the brine enthalpy (sensible heat to recover). Moreover, Option 2 ("indirect desalination") generates the loss of a small amount 
of exergy (related to the additional $\Delta \mathrm{T}$ ) since it places an exchange surface in the direct recovery of sensible heat.

The possible input of saline water from the environment brings a negligible contribution of exergy flow. From the point of view of calculations, changing the type of feed water to desalinate (e.g., geothermal brine or seawater) affects only the minimum separation work. From the process point of view, as described in the introduction, Option 1 ("direct desalination") is possible only with certain types of reservoir and specific brine composition (if an acceptable scaling/fouling is obtained). It is necessary to pretreat the process feed and to fix the recovery ratio as not to generate the precipitation of some critical salts.

This paper reports the results of process and economic analysis for the first option (direct supply of waste brine) by means of the single-effect mechanical vapor compression (MVC) desalination, which is very attractive for small to medium modular units and decentralized solutions. In this paper, a minimum potentiality of $10 \mathrm{t} / \mathrm{h}$ was selected. The process, fed with hot water, does not require an external thermal source (for both heating/evaporating and cooling) because it uses the produced vapor to evaporate the feed. The process scheme of the selected MVC apparatus is presented in Figure 10.

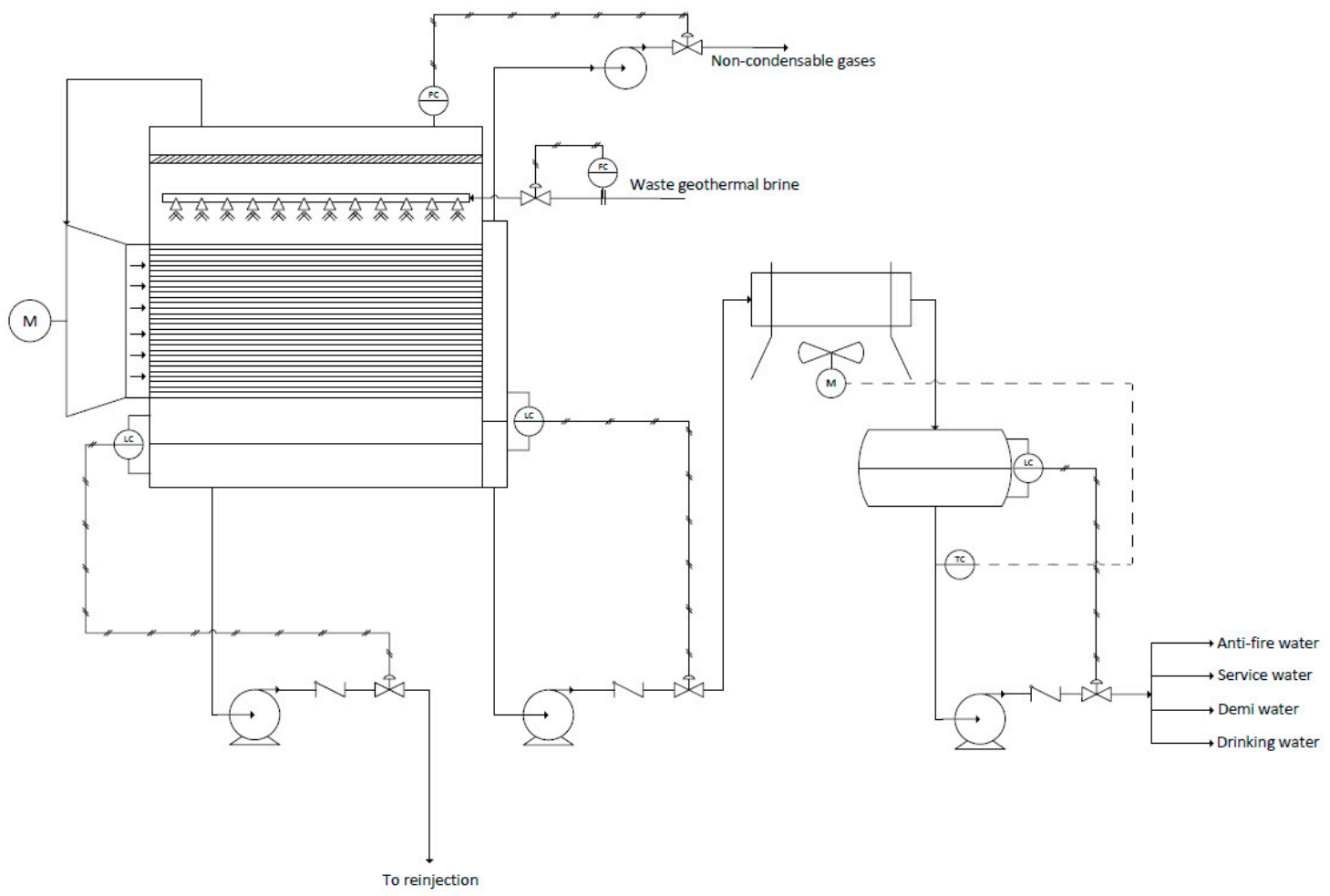

Figure 10. Simplified process scheme of the MVC desalination process under evaluation.

The MVC apparatus consists of five main elements: compressor, evaporator, inlet water preheater, brine/distillate pumps and non-condensable gases extraction system. In our case, the MVC plant is fed by a geothermal brine at around $75^{\circ} \mathrm{C}$, so there is no need for preheaters. The brine is not cooled since it is sent to the reinjection wells along with the exit brine from the power plant. The distillate is air-cooled (to reduce the water footprint of the process). The compressor is directly connected to the evaporator that includes the horizontal-tubes bundle for the falling film evaporation, the spraying nozzles, the steam suction tube and the demister. The brine is sprayed over the horizontal tubes, generating a falling film on the tubes that improves the evaporation efficiency. The generated steam is conveyed to the compressor suction through a piping line protected by demisters. The superheated steam out from the compressor condenses inside the horizontal tubes; outside the tubes the water (partially) evaporates. 
The key operational parameters are the pinch-point temperature $\Delta \mathrm{T}$ in the evaporator and the degree of vaporization of the feed $\alpha$. The net $\Delta \mathrm{T}$ (including BPE) was fixed at $5{ }^{\circ} \mathrm{C}$ to minimize the heat-exchange area. The degree of vaporization $\alpha$ was fixed according to the maximum concentration factor of the brine to avoid silica precipitation. In this case, $\alpha$ is calculated from the silica solubility at $26 \%$; in other cases additional methodologies to avoid silica scaling should be adopted (e.g., $\mathrm{pH}$ adjustment, treatment with scale/inhibitors) [46].

The process is fed with the geothermal brine described in Section 2.2 with a total salts concentration around $5000 \mathrm{ppm}$ (whose characteristics are shown in Table 2). The feed flashes and evaporates at 0.39 bar $\left(75.4{ }^{\circ} \mathrm{C}\right)$. The $74 \%$ of the feed is collected at the bottom as concentrated brine (for reinjection) and the $26 \%$ that evaporates is compressed to the saturation pressure corresponding to the evaporation temperature plus $5{ }^{\circ} \mathrm{C}\left(0.84 \mathrm{bar}, 80.4^{\circ} \mathrm{C}\right)$. The enthalpy-temperature diagram of the evaporator is available in Figure 11. The distillate is sent to an air cooler to obtain a final temperature of $40{ }^{\circ} \mathrm{C}$. The described process is controlled by regulating the feed-stream flow rate to keep the degree of vaporization equal to $26 \%$. The heat and material balances of the process were performed in the Aspen Plus environment (thermodynamic model: Electrolyte NRTL) for the capacity of $10 \mathrm{t} / \mathrm{h}$ distillate.

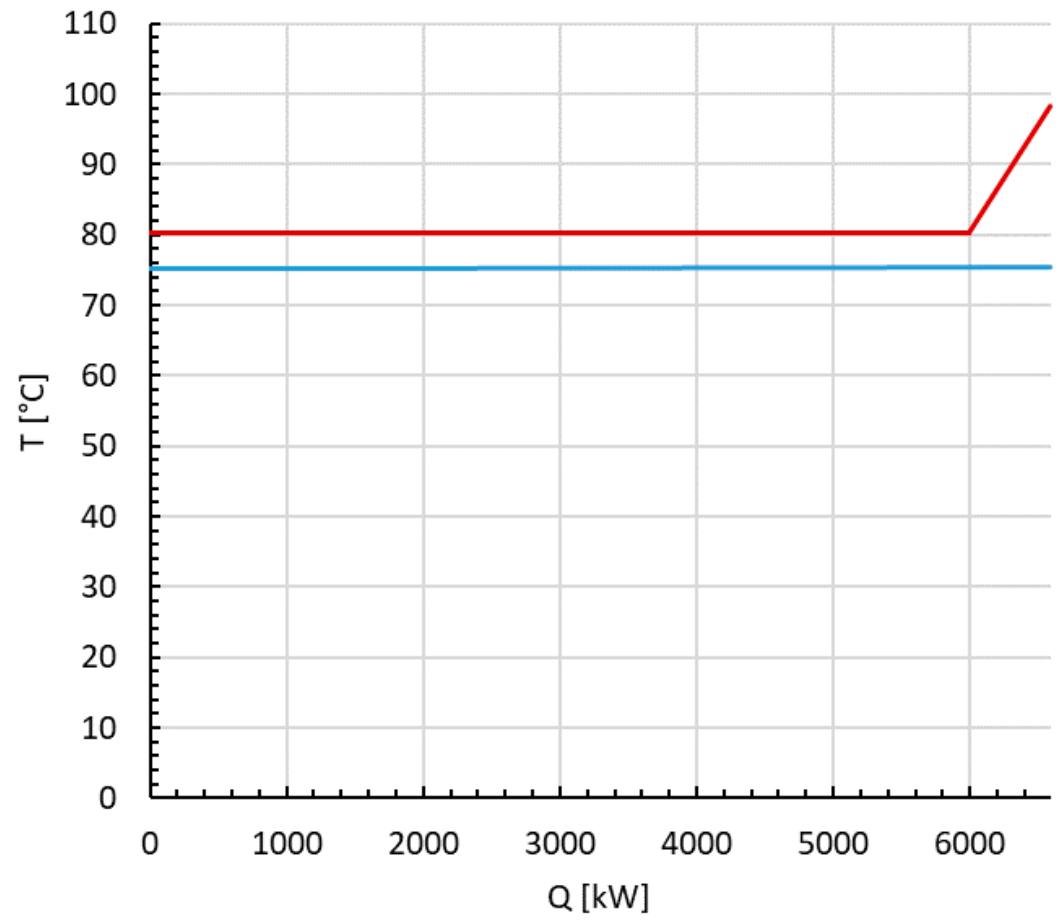

Figure 11. Temperature-enthalpy diagram of the MVC evaporator.

The basic design of the evaporator and the air cooler was carried out. The main construction and performance parameters (e.g., power consumption and the specific heat exchange area) were calculated to realize a prefeasibility economic estimation. The results are reported in Table 6.

According to these results, it is possible to state that the recovery of freshwater is feasible with a very compact and low-cost solution. The second-law efficiency (according to Equation (8)) assumes values close to $6 \%$. This is because, despite the very low exergy consumption, the $\mathrm{W}_{\text {rev }}$ is low too (given the low salinity of the feed water and the low recovery ratio). The MVC utilizes electrical energy and cannot overcome the exergy efficiency of the reverse osmosis (RO) process. For low-salinity feeds, the $\mathrm{RO}$ is thermodynamically superior, also for dual-purpose plants as discussed by Mistry et al. [39]. On the other hand, the RO process was not considered due to the water temperature and composition that generate prohibitive conditions for the membrane. This and other research groups are developing alternative thermal processes to exploit this low-grade thermal energy with higher efficiency. For 
the purpose of this work, a reliable technology (MVC), which can be the object of basic design and cost estimation, was chosen and discussed. It must also be considered that in these cases the heat is commonly dispersed into the environment. Therefore, despite the efficiencies being low, a precious good is still being produced from a waste current. The assessment of the integrated process (through Equation (9)), including the data of the power plant from which the brine is rejected, has not been carried out at the moment, as not all data relating to the Cove Fort power plant are available.

Table 6. Results from basic design, CAPEX and OPEX estimation for the MVC desalination of waste geothermal brine.

\begin{tabular}{cc}
\hline \multicolumn{2}{c}{ Process/Design Results } \\
\hline Evaporator heat exchange area & $224 \mathrm{~m}^{2}$ \\
Distillate air cooler heat exchange area & $452 \mathrm{~m}^{2}$ \\
Specific power consumption & $13.2 \mathrm{kWh} \mathrm{m}^{-3}$ \\
Specific heat exchange area & $80 \mathrm{~m}^{2} /\left(\mathrm{kg} \mathrm{s}^{-1}\right)$ \\
\hline \multicolumn{2}{c}{ Economic Results } \\
\hline Total investment cost (CAPEX) & $486 \mathrm{k€}$ \\
Total annual operating cost (OPEX) & $138 \mathrm{k€}$ \\
Total annual cost of water production (CoW) & $1.7 € / \mathrm{m}^{3}$ \\
\hline
\end{tabular}

\section{Conclusions}

Water and energy are key drivers of economic growth and social development, and the related production/use processes are intrinsically linked; there is a need to manage the issues of water and energy supply in an integrated form. Moreover, a large amount of water and energy is degraded and wasted into the environment in several forms.

This work deals with recovery processes adapted to low-enthalpy saline streams such as geothermal brines. The latter represent the best example of unexploited waste streams that can be used for water, minerals and energy recovery, and offer the ideal case study for coupling desalination and power production.

Firstly, a general thermodynamic framework of the integrated process is proposed for the characterization of the exergy balance and the second-law efficiency in water/energy production processes, and for the comparison with similar competitive technologies. This methodology is in continuity with some cited works, but specializes in the case of low-enthalpy stream and sensible heat by introducing a new corrective factor based on the destruction of exergy in the heat exchange at variable temperature (sensible heat).

Secondly, the process and economic analysis of some water and energy production that exploit geothermal brine was proposed. From the energy point of view, two ORCs were analyzed to obtain an additional production of electrical energy. Although the global thermal efficiency is around 15\%, from the point of view of second-law efficiency, these processes show considerably higher values. This means that the "available" energy is properly exploited. A basic design of the ORC is proposed; from the point of view of the remuneration of a possible investment, these choices show good profitability indexes.

As for water production, an MVC directly supplied by the geothermal brine was analyzed. The basic design was proposed together with a preliminary technical-economic analysis of the desalination plant to produce $10 \mathrm{t} / \mathrm{h}$ of freshwater from the reinjected brine. Even if high exergy performance is not attained with this technological choice, a good combination of efficiency and investment costs is achieved. In fact, with the MVC it is possible to produce low-cost water for the uses of the industrial complex. This research group and others in the world are developing technologies (currently at Technological Readiness Level, TRL 4-5) to exploit the huge potential given by wasted hot-saline currents, of which geothermal brines are an example. 
Author Contributions: Conceptualization, M.C.; Data curation, E.M.; Formal analysis, M.D.F.; Investigation, M.C., E.M. and M.D.F.; Methodology, V.P.; Project administration, M.D.F.; Resources, V.P.; Supervision, M.C. and V.P.; Writing—original draft, M.C.; Writing—review and editing, M.D.F. All authors have read and agreed to the published version of the manuscript.

Funding: This research received no external funding.

Conflicts of Interest: The authors declare no conflict of interest.

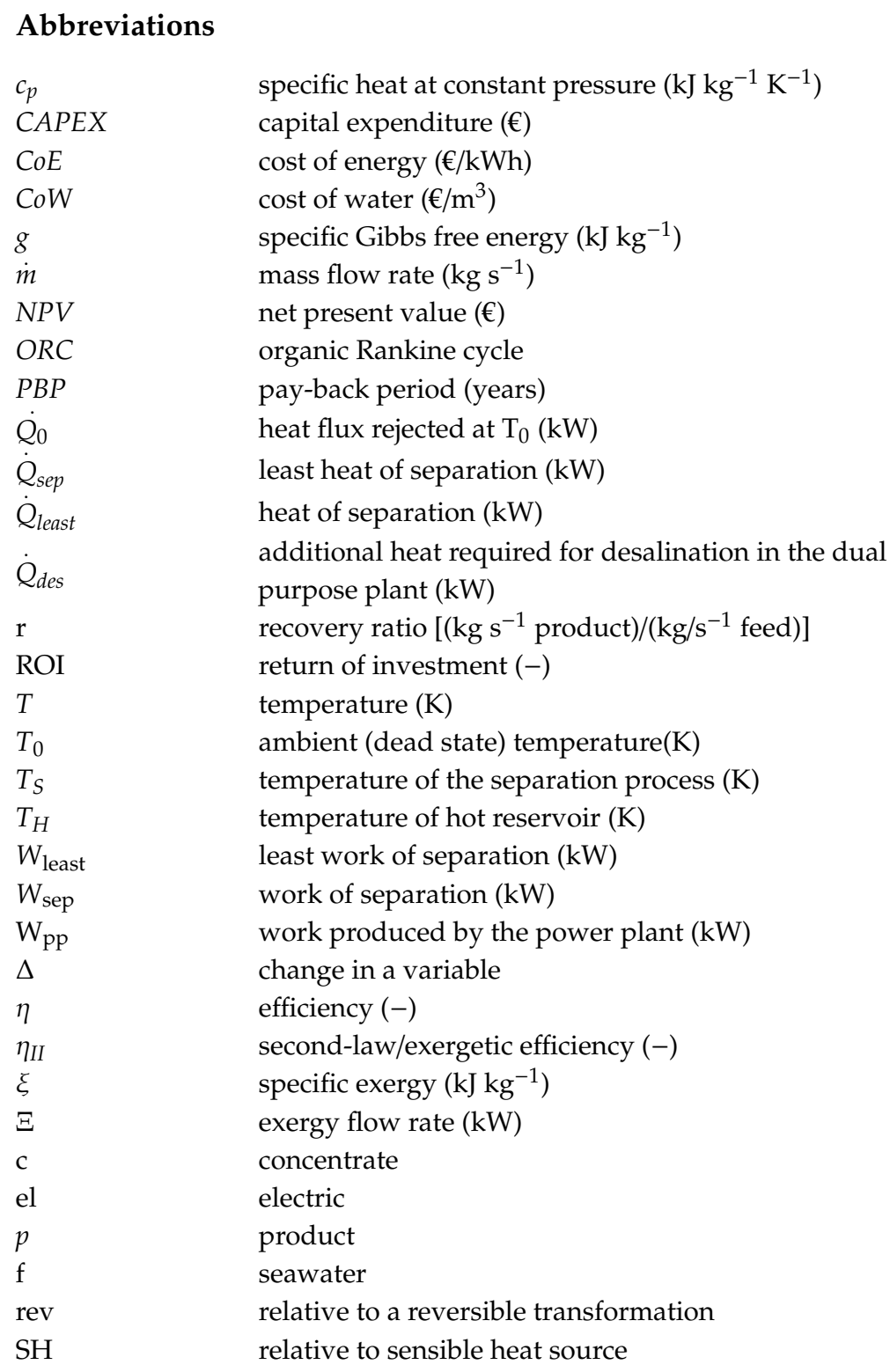

\section{References}

1. Shahzad, M.W.; Burhan, M.; Angb, L.; Ng, K.C. Energy-water-environment nexus underpinning future desalination sustainability. Desalination 2017, 413, 52-64. [CrossRef]

2. Position Paper on Water, Energy, Food and Ecosystems (WEFE) Nexus and Sustainable Development Goals (SDGs); EUR 29509 EN; Publications Office of the European Union: Luxembourg, 2018; Available online: https://op.europa.eu/en/publication-detail/-/publication/265bda85-88db-11e9-9369-01aa75ed71a1/ language-en (accessed on 14 January 2020).

3. Levy, B.S.; Sidel, V.W. Water Rights and Water Fights: Preventing and Resolving Conflicts Before They Boil Over. Am. J. Public Health 2011, 101, 5. [CrossRef] [PubMed] 
4. EU-level Instruments on Water Reuse, 2016. Final Report to Support the Commission's Impact Assessment. Amec Foster Wheeler Environment \& Infrastructure UK Ltd., IEEP, ACTeon, IMDEA and NTUA. Available online: https://ec.europa.eu/environment/water/blueprint/pdf/EU_level_instruments_on_water-2nd-IA_ support-study_AMEC.pdf (accessed on 14 January 2020).

5. Plappally, A.K.; Lienhard, V.J.H. Energy requirements for water production, treatment, enduse, reclamation, and disposal. Renew. Sustain. Energy Rev. 2012, 16, 4818-4848. [CrossRef]

6. Pan, S.-Y.; Snyder, S.W.; Packman, A.I.; Lin, Y.J.; Chiang, P.-C. Cooling water use in thermoelectric power generation and its associated challenges for addressing water-energy nexus. Water-Energy Nexus 2018, 1, 26-41. [CrossRef]

7. Ammara, Y.; Li, H.; Walsh, C.; Thornley, P.; Sharifi, V.; Roskilly, A.P. Desalination using low grade heat in the process industry: Challenges and perspectives. Appl. Therm. Eng. 2013, 53, 234-245. [CrossRef]

8. Gao, H.; Scherson, Y.D.; Wells, G.F. Towards energy neutral wastewater treatment: Methodology and state of the art. Environ. Sci. Process. Impacts 2014, 16, 1223-1246. [CrossRef]

9. Scherson, Y.D.; Criddle, C.S. Recovery of freshwater from wastewater: Upgrading process configurations to maximize energy recovery and minimize. Resid. Environ. Sci. Technol. 2014, 48, 842-8432. [CrossRef]

10. Cipollina, A.; Micale, G. Sustainable Energy from Salinity Gradients; Elsevier: Amsterdam, The Netherlands, 2016; ISBN 978-0-08-100312-1.

11. Drioli, A.E.; Ali, F.; Macedonio, C.A. Quist-Jensen. Minerals, energy and water from the sea: A new strategy for zero liquid discharge in desalination. JSM Environ. Sci. Ecol. 2015, 3, 1018.

12. Lienhard, J.H.; Thiel, G.P.; Warsinger, D.M.; Banchik, L.D. Low Carbon Desalination: Status and Research, Development, and Demonstration Needs; MIT Abdul Latif Jameel World Water and Food Security Lab: Cambridge, MA, USA, 2016.

13. Capocelli, M.; Prisciandaro, M.; Piemonte, V.; Barba, D. A technical-economical approach to promote the water treatment \& reuse processes. J. Clean. Prod. 2019, 207, 85-96.

14. Schultze, L.E.; Bauer, D.J. Recovering Lithium Chloride from a Geothermal Brine; Bureau of Mines, United States Department of the Interior: Washington, DC, USA, 1984.

15. Harrison, S. Technologies for Extracting Valuable Metals and Compounds from Geothermal Fluids Geothermal Technologies Program US Department of Energy (2010). Available online: https://www.energy.gov/sites/ prod/files/2014/02/f7/specialized_harrison_extracting_metals.pdf (accessed on 14 January 2020).

16. Meckler, M. Geothermal Mineral Extraction System. US Patent 4,211,613, 7 August 1980.

17. Gude, V.G. Geothermal source potential for water desalination-Current status and future perspective. Renew. Sustain. Energy Rev. 2016, 57, 1038-1065. [CrossRef]

18. Wong, C.M. Geothermal Energy and Desalination: Partners in Progress Geothermic. In Proceedings of the U.N. Symposium on the Development and Utilization of Geothermal Resources 2, Pisa, Italy, 22 September-1 October 1970.

19. Direct Use of Geothermal Resources. Available online: https://nea.is/geothermal/direct-utilization/ (accessed on 10 November 2019).

20. Statista Energy and Environmental Services-Electricity-Global Geothermal Capacity from 2008 to 2018. Available online: https:/www.statista.com/statistics/476281/global-capacity-of-geothermal-energy/ (accessed on 10 November 2019).

21. Sigfusson, B.; Uihlein, A. 2014 JRC Geothermal Energy Status Report; EUR 27623 EN; Publications Office of the European Union: Luxembourg, 2015. [CrossRef]

22. Di Pippo, R. Geothermal Power Plants: Principles, Applications, Case Studies and Environmental Impact; Butterworth-Heinemann: Oxford, UK, 2007.

23. Özkaraca, O.; Keçeba, P.; Demircan, C.; Keçeba, A. Thermodynamic Optimization of a Geothermal-Based Organic Rankine Cycle System Using an Artificial Bee Colony Algorithm. Energies 2017, 10, 1691. [CrossRef]

24. Olasolo, P.; Juárez, M.C.; Morales, M.P.; D'Amico, S.; Liarte, I.A. Enhanced geothermal systems (EGS): A review. Renew. Sustain. Energy Rev. 2016, 56, 133-144. [CrossRef]

25. Belessiotis, V.; Delyannis, E. Water shortage and renewable energies (RE) desalination -possible technological applications. Desalination 2001, 139, 133-138. [CrossRef]

26. Missimer, T.M.; Ng, K.C.; Thuw, K.; Shahzad, M.W. Geothermal electricity generation and desalination: An integrated process design to conserve latent heat with operational improvements. Desalin. Water Treat. 2016, 57, 23110-23118. [CrossRef] 
27. Bourouni, K.; Deronzier, J.C.; Tadrist, L. Experimentation and modelling of an innovative geothermal desalination unit. Desalination 1999, 125, 147-153. [CrossRef]

28. Bouguecha, S.; Dhahbi, M. Fluidised bed crystalliser and air gap membrane distillation as a solution to geothermal water desalination. Desalination 2003, 152, 237-244. [CrossRef]

29. Davies, P.A.; Orfi, J. Self-Powered Desalination of Geothermal Saline Groundwater: Technical Feasibility. Water 2014, 6, 3409-3432. [CrossRef]

30. Astolfi, M.; Romano, M.C.; Bombarda, P.; Macchi, E. Binary ORC (organic Rankine cycles) power plants for the exploitation of medium-low temperature geothermal sources-Part A: Thermodynamic optimization. Energy 2014, 66, 423-434. [CrossRef]

31. Astolfi, M.; Romano, M.C.; Bombarda, P.; Macchi, E. Binary ORC (organic Rankine cycles) power plants for the exploitation of medium-low temperature geothermal sources-Part B: Techno-economic optimization. Energy 2014, 66, 435-446. [CrossRef]

32. Loganathan, G.N.; Saravanamuthu, V. Mining valuable minerals from seawater: A critical review. Environ. Sci. Water Res. Technol. 2017, 3, 37. [CrossRef]

33. Bell, J.C. Availability of Geothermal Energy for the Demineralization of Saline Water; U.S. Department of the Interior: Washington, DC, USA, 1959.

34. Christ, A. A Novel Sensible Heat Driven Desalination Technology. Ph.D. Thesis, University of Western Australia, Perth, Australia, 2015.

35. Capocelli, M.; Di Paola, L.; De Falco, M.; Piemonte, V.; Barba, D. A novel process of humidificationdehumidification with brine recirculation for desalination in remote areas of the world. Desalin. Water Treat. 2017, 69, 244-251. [CrossRef]

36. Capocelli, M.; Balsamo, M.; Lancia, A.; Barba, D. Process analysis of a novel humidificationdehumidification-adsorption (HDHA) desalination method. Desalination 2018, 429, 155-166. [CrossRef]

37. Elminshawy, N.A.S.; Siddiqui, F.R.; Addas, M.F. Development of an active solar humidificationdehumidification (HDH) desalination system integrated with geothermal energy. Energy Convers. Manag. 2016, 126, 608-621. [CrossRef]

38. Sarbatly, R.; Chiam, C.-K. Evaluation of geothermal energy in desalination by vacuum membrane distillation. Appl. Energy 2013, 112, 737-746. [CrossRef]

39. Mistry, K.H.; Lienhard V, J.H. Generalized Least Energy of Separation for Desalination and Other Chemical Separation Processes. Entropy 2013, 15, 2046-2080. [CrossRef]

40. Calise, F.; D'Accadia, M.D.; Macaluso, A.; Piacentino, A.; Vanoli, L. Exergetic and exergoeconomic analysis of a novel hybrid solar-geothermal polygeneration system producing energy and water. Energy Convers. Manag. 2016, 115, 200-220. [CrossRef]

41. Behnam, P.; Arefi, A.; Shafii, M.B. Exergetic and thermoeconomic analysis of a trigeneration system producing electricity, hot water, and fresh water driven by low-temperature geothermal sources. Energy Convers. Manag. 2018, 157, 266-276. [CrossRef]

42. Mistry, K.H.; McGovern, R.K.; Thiel, G.P.; Summers, E.K.; Zubair, S.M.; Lienhard V, J.H. Entropy Generation Analysis of Desalination Technologies. Entropy 2011, 13, 1829-1864. [CrossRef]

43. Lienhard, V.J.H.; Mistry, K.H.; Sharqawy, M.H.; Thiel, G.P. Desalination Sustainability: A Technical, Socioeconomic, and Environmental Approach; Arafat, H.A., Ed.; Elsevier: Amsterdam, The Netherlands, 2017.

44. Lienhard, V.J.H. Energy Efficiency, Primary Energy, and Apples vs. Oranges. IDA Global Connections, Winter 2019, International Desalination Association. pp. 31-33. Available online: https:/dspace.mit.edu/bitstream/handle/ 1721.1/121047/LIENHARD-IDA-Global-Connections_Winter-2019.pdf?sequence=1\&isAllowed=y (accessed on 15 January 2020).

45. De Falco, M.; Capocelli, M. Process Analysis and Plant Simulation in a Sustainable Economy Studies in Surface Science and Catalysis; Elsevier: Amsterdam, The Netherlands, 2019; Volume 179, pp. 121-140, Chapter 8.

46. Von Hirtz, P. Silica scale control in geothermal plants-Historical perspective and current technology. In Geothermal Power Generation; DiPippo, R., Ed.; Elsevier: Amsterdam, The Netherlands, 2016; pp. 443-476.

(C) 2020 by the authors. Licensee MDPI, Basel, Switzerland. This article is an open access article distributed under the terms and conditions of the Creative Commons Attribution (CC BY) license (http://creativecommons.org/licenses/by/4.0/). 